\title{
RETROSPECTIVE DESCRIPTIVE STUDY ON PATTERN OF INJURIES, MODE OF ACCIDENT, MORTALITY AND ALCOHOL ASSOCIATION IN ROAD TRAFFIC ACCIDENTS FOR 3 YEARS 2013 - 2015 IN GOVERNMENT VELLORE MEDICAL COLLEGE HOSPITAL, VELLORE, TAMILNADU - INSTITUTIONAL STUDY IN TERTIARY CARE CENTRE
}

\author{
R. Soundarapandiyan ${ }^{1}$, R. Rajavelu 2 , V. Udhayasankar ${ }^{3}$
}

1 Professor, Department of General Surgery, Government Vellore Medical College, Vellore. 2 Professor, Department of General Surgery, Government Vellore Medical College, Vellore. 3Junior Resident, Department of General Surgery, Government Vellore Medical College, Vellore.

\section{ABSTRACT}

\section{BACKGROUND}

Road traffic accidents are the leading cause of death in all injuries and tenth leading cause of death globally, RTA are increasing alarmingly worldwide and causes the increased morbidity and mortality. Patients presenting with RTA has different pattern of injuries, different modes of accident and with or without intoxication with alcohol or drug use.

\section{MATERIALS AND METHODS}

Retrospective study on Road Traffic Accidents (RTA) conducted in the Government Vellore Medical College, Vellore, Tamilnadu, Tertiary Care Centre for the period from 1st January 2013 to December 2015, 3 years. All the patients are included in the study who got admitted through our Casualty with alleged history of Road Traffic Accidents. This present retrospective study aims to know the pattern of injuries, mode of accident, mortality and alcohol association in patients of RTAs. Implementation of effective safety measures to prevent the RTAs is very much essential.

\section{RESULTS}

Total of 13946 cases were analysed, among them 11015 were males and 2931 were females. Males were most commonly involved in the male-to-female ratio of 3.75 to 1 . Most number of RTA victims found between the age group of 18 - 30 years, both in males as well as in females (31\%, 26\%). Highest number of RTA occurs with two wheeler rider followed by pillion $(31.28 \%, 24.19 \%)$. Common pattern of injury is abrasion $27.35 \%$ followed by fractures/dislocations $21.79 \%$, bruise/contusion $18.1 \%$ and laceration $14.35 \%$. The most common anatomical region involved is lower extremity $33.45 \%$ followed by upper extremity $28.14 \%$. Both the anatomical regions constitute around $62 \%$ of anatomical regions, which is followed by head and neck $31.16 \%$; $45.02 \%$ RTA victims as breath smell of alcohol this constitutes both the riders as well as pillion riders, pedestrians and all types of vehicular RTA victims. Alcohol associated with mortality is also higher 198 cases among 442 mortality.

\section{CONCLUSION}

In this study, highest number of RTA victims are young males who are either two wheeler rider or pillion rider. Abrasions, followed fractures are the commonest type of injuries. Commonest cause of mortality is due to head injury. The strict licensure procedure should be followed and minimum level of education regarding road safety should be imparted, especially to the young age group during giving license.

\section{KEYWORDS}

RTA, Pattern of Injuries, Vehicles.

HOW TO CITE THIS ARTICLE: Soundarapandiyan R, Rajavelu R, Udhayasankar V. Retrospective descriptive study on pattern of injuries, mode of accident, mortality and alcohol association in road traffic accidents for 3 years 2013 - 2015 in Government Vellore medical college hospital, Vellore, Tamilnadu - institutional study in tertiary care centre. J. Evolution Med. Dent. Sci. 2016;5(92): 68096812, DOI: $10.14260 /$ jemds/2016/1540

\section{BACKGROUND}

Road traffic accidents are eighth leading cause of death globally. About 1.24 million people died due to RTA worldwide; 50 million people are affected with non-fatal injuries. ${ }^{1}$ According to National Crime Record Bureau about $1,39,091$ people died in 4,40,042 accidents throughout the

Financial or Other, Competing Interest: None.

Submission 29-10-2016, Peer Review 10-11-2016,

Acceptance 12-11-2016, Published 16-11-2016.

Corresponding Author:

Dr. R. Soundarapandiyan,

\#116, II ${ }^{\text {nd }}$ Cross Street,

Bishop David Nagar,

Vellore-632001, Tamilnadu.

E-mail: drrsoundar7@gmail.com

DOI: $10.14260 /$ jemds $/ 2016 / 1540$
India. In this $1,18,533$ victims were males. Tamilnadu tops the mortality due to trauma deaths 16,175 deaths in 67,757 accidents. Tamilnadu accounts for $15.4 \%$ of deaths and also it was the 3 rd most common place where drunken drive related traffic accidents took place. ${ }^{2}$

RTA is any vehicular accident occurring on the roadway that is originating on, terminating on or involving a vehicle partially on the roadway. This includes automobiles vs pedestrian or another automobile or fall from automobile. In developing countries like us RTA's growing as major epidemiological burden, this is due to growing population, increase in number of vehicles, high speed technology in vehicles and also the poor roads and without the safety precautions. This along with intoxication like drugs, alcohol, etc. 
Victims sustain variety of injuries in different parts of the body. Injuries may be external or internal. The study of pattern of injuries helps to prevent mortality and apply the safety implications.

\section{Objectives of the Study}

1. Age and sex distribution of injured in road traffic accidents (RTA).

2. Distribution of injured in road traffic accidents by mode of transport and victim role.

3. Pattern of injuries sustained.

4. Alcohol association with RTA.

5. Alcohol association with mortality.

\section{MATERIALS AND METHODS}

This study was conducted in Government Vellore Medical College Hospital, Vellore, Tamilnadu, Tertiary Care Centre and District Level Hospital from 1st January 2013 to 30th December 2015.

\section{Inclusion Criteria}

All the patients who got admitted to the Government Vellore Medical College Hospital, and the data collected from the Accident Register maintained in the casualty and also the case sheets of the patients through Medical Records Department.

\section{Exclusion Criteria}

The following cases were excluded from the study, cases treated as OPD after accident register entry and brought dead cases.

\section{Anatomical Site of Injury}

For this study purpose, the Anatomical regions can be divided into following regions.

1. Head and Neck.

2. Upper Extremity.

3. Lower Extremity.

4. Abdomen and Chest.

\section{Pattern of Injuries}

For this study purpose, injuries are categorised as follows,

1. Fractures/Dislocations.

2. Head Injury.

3. Abrasion.

4. Bruises/Contusions.

5. Lacerations.

6. Visceral Injury (Blunt injury Chest and Abdomen).

\section{OBSERVATION AND RESULTS}

Total of 13946 cases were analysed, among them 11015 were males and 2931 were females.

\begin{tabular}{|c|c|c|c|c|c|c|}
\hline Age & Male (n) & $\%$ & Female (n) & $\%$ & Total (n) & $\%$ \\
\hline$<18$ & 1211 & 10.9 & 238 & 8.1 & 1449 & 10.40 \\
\hline $18-30$ & 3415 & 31 & 762 & 26 & 4177 & 29.95 \\
\hline $31-40$ & 2644 & 24 & 703 & 24 & 3347 & 24 \\
\hline $41-50$ & 1653 & 15.1 & 481 & 16.4 & 2134 & 15.30 \\
\hline $51-60$ & 1110 & 10.1 & 334 & 11.4 & 1444 & 10.35 \\
\hline$>60$ & 982 & 8.9 & 413 & 14.1 & 1395 & 10 \\
\hline Total & 11015 & & 2931 & & 13946 & \\
\hline
\end{tabular}

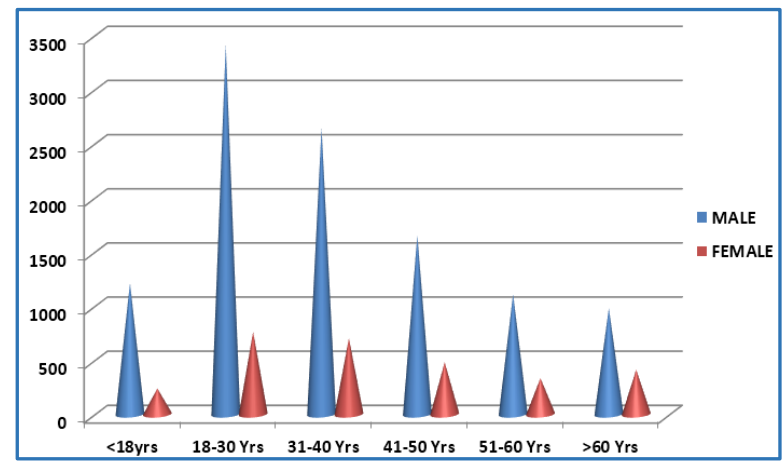

Figure 1. Shows Age and Sex Wise Distribution of Cases

Table 1 and Figure 1 shows age and sex distribution of RTA cases. Among this most common age group involved is 18 - 40 yrs.

\begin{tabular}{|c|c|c|}
\hline Vehicle & Number of Cases & $\%$ \\
\hline Pedestrian & 1953 & 14 \\
\hline Bicycle & 215 & 1.55 \\
\hline Two wheeler rider & 4362 & 31.28 \\
\hline Two wheeler pillion & 3374 & 24.19 \\
\hline Three wheeler & 1150 & 8.25 \\
\hline Four wheeler & 1876 & 13.45 \\
\hline Heavy motor vehicles & 1016 & 7.28 \\
\hline $\begin{array}{r}\text { Table 2. Show } \\
\text { according to } 1 \\
\end{array}$ & $\begin{array}{l}\text { istribution of } \mathrm{C} \\
\text { e of Vehicle Inv }\end{array}$ & \\
\hline
\end{tabular}

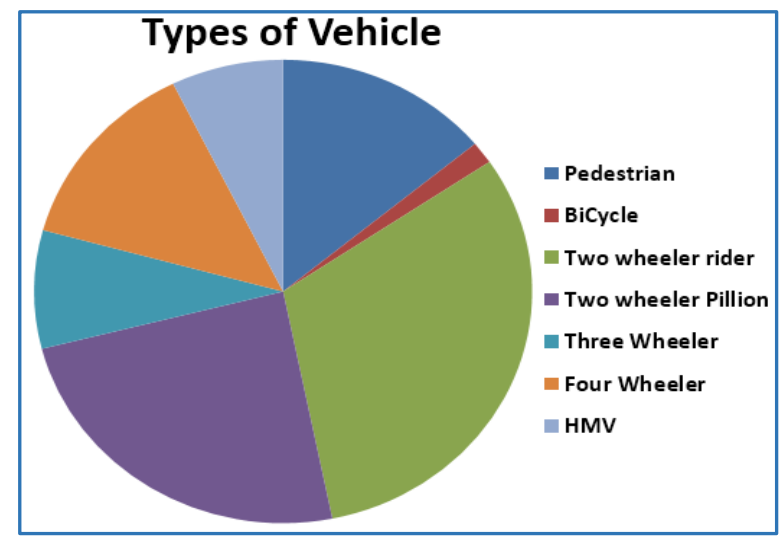

Figure 2. Shows Distribution of Cases according to Type of Vehicle Involved

Table 2 and Figure 2 shows the types of vehicles involved in RTA. Among this two wheeler rider and pillion followed by pedestrian and four wheeler.

\begin{tabular}{|c|c|c|c|c|c|}
\hline $\begin{array}{c}\text { Pattern of } \\
\text { Injuries }\end{array}$ & $\begin{array}{c}\text { No. of } \\
\text { Cases } \\
\text { (n) }\end{array}$ & $\mathbf{\%}$ & $\begin{array}{c}\text { Anatomical } \\
\text { Region } \\
\text { Involved }\end{array}$ & $\begin{array}{c}\text { No. } \\
\text { of Cases } \\
\text { (n) }\end{array}$ & $\%$ \\
\hline $\begin{array}{c}\text { Fracture/ } \\
\text { Dislocation }\end{array}$ & 3039 & 21.79 & Head \& Neck & 2951 & 21.16 \\
\hline Head Injury & 1556 & 11.16 & $\begin{array}{c}\text { Upper } \\
\text { Extremity }\end{array}$ & 3952 & 28.34 \\
\hline Abrasion & 3814 & 27.35 & $\begin{array}{c}\text { Lower } \\
\text { Extremity }\end{array}$ & 4665 & 33.45 \\
\hline $\begin{array}{c}\text { Bruise/ } \\
\text { Contusion }\end{array}$ & 2524 & 18.10 & $\begin{array}{c}\text { Abdomen \& } \\
\text { Perineum }\end{array}$ & 1429 & 10.25 \\
\hline Laceration & 2002 & 14.35 & Thorax & 949 & 6.8 \\
\hline $\begin{array}{c}\text { Visceral } \\
\text { Injury }\end{array}$ & 1011 & 7.25 & & & \\
\hline \multicolumn{7}{|c|}{$\begin{array}{c}\text { Table 3. Shows Pattern of Injuries } \\
\text { and Anatomical Region Involved }\end{array}$} \\
\hline \multicolumn{7}{|c|}{}
\end{tabular}




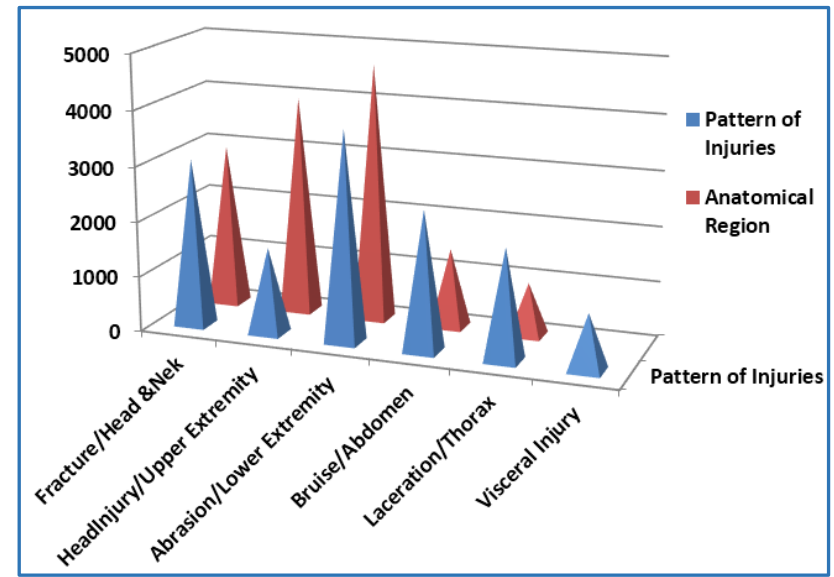

Figure 3. Shows Pattern of Injuries and Anatomical Region Involved

Table 3 and Figure 3 shows the pattern of injuries and anatomical region involved. Most common pattern of injury is abrasion and most common anatomical region involved is lower extremity.

\begin{tabular}{|c|c|c|c|c|c|c|c|}
\hline $\begin{array}{c}\text { Mortality } \\
\text { in RTA } \\
\text { Due To }\end{array}$ & $\begin{array}{c}\text { Alcoholic } \\
\text { (n) }\end{array}$ & $\%$ & $\begin{array}{c}\text { Non } \\
\text { Alcoholic } \\
\text { (n) }\end{array}$ & $\%$ & RTA & $\begin{array}{c}\text { No. } \\
\text { of } \\
\text { Cases }\end{array}$ & $\%$ \\
\hline Head Injury & 142 & 71.71 & 153 & 65.38 & Alcoholic & 6278 & 45.02 \\
\hline $\begin{array}{c}\text { Other } \\
\text { Causes }\end{array}$ & 56 & 28.29 & 91 & 34.62 & $\begin{array}{c}\text { Non- } \\
\text { Alcoholic }\end{array}$ & 7668 & 54.98 \\
\hline \multicolumn{7}{c|}{ Table 4. Shows Alcoholic Association } \\
with RTA and Mortality \\
\hline
\end{tabular}

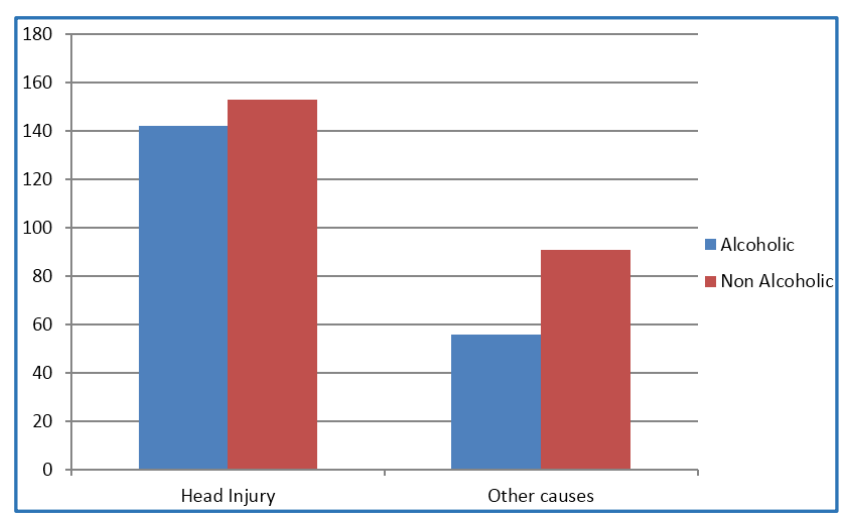

Figure 4. Shows Alcoholic association with RTA Mortality

Table 4 and Figure 4 shows alcohol association with RTA and mortality nearly of the deaths due to RTA, and RTA as such involved with alcoholic intoxication.

\section{DISCUSSION}

In this study, males are most commonly involved in the maleto-female ratio of 3.75 to 1 . The most of the studies shows the same result where males outnumbered the female population. 4,5 Most of the studies in RTA were found to have the same results, so males are exposed more to the RTA.

In this study most number of RTA victims found between the age group of 18 - 30 years, both in males as well as in females $(31 \%, 26 \%)$ followed by the age group of 31 - 40 years $(24 \%, 24 \%)$. That is most of the RTA involved between the age group of 18 - 40 years.

This is productive age group in both males and females in a modernised world where both family members earning, which adds serious economic loss to the family as well as to the community.5,6
In this study, highest number of RTA occurs with two wheeler rider followed by pillion (31.28\%, 24.19\%). Both of them constitutes nearly $56 \%$ of the all types of vehicular injuries.5,6 This is because our district which has a mixed population, two wheelers are the common mode of transport used by the people. This study is against some studies done in urban centres. ${ }^{7}$ Our tertiary care centre which surrounds by the rural public and by the most number two wheeler users. Even though the people are depending on the public transport, the RTAs due to public transport that is Heavy Motor Vehicle is low.

In this study, common pattern of injury is abrasion $27.35 \%$ followed by fractures/dislocations $21.79 \%$, bruise/contusion $18.1 \%$ and laceration $14.35 \%$. The most common anatomical region involved is lower extremity $33.45 \%$ followed by upper extremity $28.14 \%$. Both the anatomical regions constitute around $62 \%$ of anatomical regions, which is followed by head and neck $31.16 \%$.

In the present study around $45.02 \%$ RTA victims as breath smell of alcohol, this constitutes both the riders as well as pillion riders, pedestrians and all types of vehicular RTA victims. Alcohol associated with mortality is also higher 198 cases among 442 mortality.

The most of the mortality is due to Head Injury both in Alcoholic and Non-Alcoholics. This implies that alcohol definitely impairs the concentration and driving ability whatever it may be the concentration.

Motor cyclists had the more mortality due to head injury in the present study. This is due to lack of protective wear, that is victims are not wearing the helmets.

\section{CONCLUSION}

In this study highest number of RTA victims are young males who are either two wheeler riders or pillion riders. Abrasions followed fractures are the commonest type of injuries. Commonest cause of mortality is due to head injury. Improvement of driving conditions, roadway lights, displaying of traffic signs, creating more turn only lines at intersections and creating more divided highways are needed.

Strict enforcement of laws regarding driving of vehicles, wearing of helmets, applying seat belts are needed along with strengthening of the health facilities for the victims.

\section{Recommendations}

The strict licensure procedure should be followed and minimum level of education regarding road safety should be imparted, especially to the young age group during giving license. Road safety education should be incorporated in curriculum of primary, middle and higher level of school students.

The use of properly designed helmet should be made compulsory, especially among the riders and pillion riders of motorised two wheelers. This might be effective in reducing head injuries.

Strict punishment for the persons who are driving with intoxicated substances such as alcohol reduces the RTA and mortality due to alcohol.

\section{REFERENCES}

1. World Health Organization. Estimates of mortality by causes for WHO member states for the year 2008 summary tables. Geneva: WHO 2011. 
2. Road accidents in India 2011. New Delhi: Transport Research Wing, Ministry of Road Transport and Highways, Government of India 2012.

3. Ghosh PK. Epidemiological study of the victims of vehicular accidents in Delhi. J of Indian Medical Association 1992;90(12):309-12.

4. Singh H, Dhattarwal SK. Pattern and distribution of injuries in fatal road traffic accidents in Rohtak (Haryana). JIAFM 2004;26(1):20-3.
5. Choudhary BL, Deepak S, Tirpude BH, et al. Profile of road traffic accidents cases in Kasturba hospital of MGIMS, Seagram, Wareham, Maharashtra. Medico Legal Update 2005;5(4):1-12.

6. Kumar DR, Raju GM, Vijayanath V, et al. Deaths due to fatal road traffic accidents: a retrospective study. J Indian Acad Forensic Med 2013;35(3):236-8.

7. Srivastav AK, Gupta RK. A study of fatal road accidents in Kanpur. J Ind Acad Foren Med 1989;11(1):24-8. 